\title{
PENGARUH KUALITAS PRODUK DAN HARGA \\ TERHADAP KEPUASAN KONSUMEN \\ PT XL AXIATA TBK \\ (Studi Kasus Mahasiswa Politeknik Negeri Medan)
}

\author{
Andriasan Sudarso ${ }^{1}$, Berjalius ${ }^{2}$ \\ ${ }^{1}$ Dosen Tetap Sekolah Tinggi Ilmu Ekonomi IBBI Medan \\ andriasans@gmail.com \\ ${ }^{2}$ Program Studi Manajemen Sekolah Tinggi Ilmu Ekonomi IBBI Medan \\ berjaliusmunthe@ymail.com
}

\begin{abstract}
Abstrak
Tujuan penelitian ini adalah untuk mengetahui pengaruh Kualitas Produk dan Harga terhadap Kepuasaan Konsumen (studi kasus mahasiswa Politeknik Negeri Medan). Jenis Penelitian ini adalah penelitian deskripsi kuantitatif dengan jenis dan sumber data yang digunakan adalah data primer dan data sekunder. Teknik Pengumpulan data yang digunakan adalah dengan wawancara, memberikan daftar pertanyaan (kuesioner). Metode analisis data yang digunakan regresi linear berganda. Populasi dalam penelitian ini adalah 45 orang. Jumlah sample penelitian menggunakan sample jenuh, yakni teknik yang mewakili populasi sebanyak 45 orang.

Hasil penelitian yang diperoleh dan sekaligus menjadi kesimpulan penelitian adalah nilai $t_{\text {hitung variabel }}$ kualitas produk adalah 6,133 dan $t_{\text {tabel }}$ bernilai 1,70 sehingga $t_{\text {hitung }}>t_{\text {tabel }}$, yaitu 6,133>1,70 dan $t_{\text {hitung }}$ variabel harga adalah $-2,292$ dan nilai $t_{\text {tabel }}$ bernilai 1,70 sehingga $-2,292<1,70$. Dapat disimpulkan bahwa variabel kualitas produk (X1) berpengaruh signifikan terhadap kepuasan konsumen PT XL Axiata Tbk dan variabel harga (X2) berpengaruh negatif dan signifikan terhadap kepuasan konsumen PT XL Axiata Tbk.
\end{abstract}

Kata Kunci : Kualitas Produk, Harga, dan Kepuasan Konsumen.

\section{PENDAHULUAN}

Komunikasi adalah hal yang sangat penting, karena dengan komunikasi seseorang akan terhubung dengan orang lain baik itu ketika berada disuatu tempat secara bersama maupun bila sedang berjauhan, ketika sedang berjauhanlah seseorang butuh media komunikasi untuk menghubungkannya dengan orang lain yang sedang berjauhan dengan dirinya. Zaman dahulu, untuk melakukan komunikasi jarak jauh sangatlah sulit bila 
dibandingkan dengan masa sekarang. Media yang digunakan juga bervariasi, ada yang menggunakan hewan seperti burung merpati, kurir pengantar berita, maupun dengan simbol-simbol tertentu seperti asap dan lain sebagainya. Selain tingginya tingkat ketidakpastian apakah berita tersampaikan dengan benar, biaya yang besar dan waktu yang lama, balasan dari penerima pun sangat tidak pasti ada atau tidak. Saat ini manusia sudah sangat dimudahkan untuk berkomunikasi satu dengan yang lainnya dalam komunikasi jarak jauh, hal ini dikarenakan semakin tingginya tingkat pengetahuan manusia dan semakin berkembangnya teknologi pada banyak bidang kehidupan termasuk dalam komunikasi. Pada tahun 1984 PT Telkom Indonesia mulai memperkenalkan teknologi komunikasi seluler di Indonesia hingga pada tahun 1996 PT Excelcomindo Pratama Tbk. mulai memasuki sektor telekomunikasi GSM kini berganti nama menjadi PT XL Axiata. Hingga sekarang terdapat banyak perusahaan yang ikut meramaikan bisnis telekomunikasi ini sehingga persaingan untuk mendapatkan pelanggan dan laba adalah hal yang yang penting. Namun tidak cukup sampai disitu, perlu juga bagi perusahaan untuk memberikan pelayanan yang tepat kepada konsumen, sehingga konsumen menjadi puas dan akan loyal kepada produk perusahaan yang pada akhirnya akan memberikan keuntungan bagi perusahaan. Untuk menjaga kinerja perusahaan dalam memberikan pelayanan dan menciptakan kepuasan kepada pelanggannya, perusahaan perlu mengetahui kebutuhan konsumen dan sudah sejauh mana produk mampu memberikan kepuasan bagi pelanggan. Semakin banyak pesaing yang menjual produk yang sama akan mempengaruhi jumlah pemjualan dan pendapatan perusahaan. Karena semakin banyak pilihan bagi pelanggan sehingga perusahaan akan berbagi pelanggan secara alami dan menurunkan jumlah pelanggan. Berikut data penurunan jumlah pelanggan PT XL Axiata Tbk. yaitu:

\begin{tabular}{|c|c|c|}
\hline Nomor & Tahun & $\begin{array}{c}\text { Jumlah } \\
\text { Pelanggan }\end{array}$ \\
\hline 1 & 2014 & 68,5 Juta \\
\hline 2 & 2015 & 52,1 Juta \\
\hline
\end{tabular}

Berdasarkan pembagian angket yang dilakukan oleh peneliti dengan menggunakan indikator kepuasan menurut ahli (Kotler:2008), dan (Fandy Tjiptono:2008) ditemukan hasil sebagai berikut:

Tabel 1.2. Kepuasan Konsumen PT XL Axiata Tbk.

\begin{tabular}{|c|l|c|l|}
\hline No. & $\begin{array}{l}\text { Indikator } \\
\text { Kepuasan }\end{array}$ & Hasil & Keterangan \\
\hline 1. & $\begin{array}{l}\text { Menjadi } \\
\text { lebih setia }\end{array}$ & 99 & $\begin{array}{l}\text { Menjadi lebih } \\
\text { setia }\end{array}$ \\
\hline 2. & $\begin{array}{l}\text { Membeli } \\
\text { lebih banyak }\end{array}$ & 99 & $\begin{array}{l}\text { Membeli } \\
\text { lebih banyak }\end{array}$ \\
\hline 3. & $\begin{array}{l}\text { Rekomendasi } \\
\text { kepada orang } \\
\text { lain }\end{array}$ & 86 & $\begin{array}{l}\text { Tidak } \\
\text { merekomend } \\
\text { asikan }\end{array}$ \\
\hline 4. & $\begin{array}{l}\text { Prioritaskan } \\
\text { produk lebih } \\
\text { dari pesaing }\end{array}$ & 90 & $\begin{array}{l}\text { Tidak } \\
\text { menjadi } \\
\text { prioritas }\end{array}$ \\
\hline 5. & $\begin{array}{l}\text { Memberikan } \\
\text { komentar } \\
\text { yang } \\
\text { menguntung } \\
\text { kan } \\
\text { perusahaan }\end{array}$ & 101 & $\begin{array}{l}\text { Menjadi } \\
\text { berkomentar } \\
\text { lebih positif }\end{array}$ \\
\hline 6. & $\begin{array}{l}\text { Kepuasan } \\
\text { daya guna }\end{array}$ & 99 & $\begin{array}{l}\text { Menjadi lebih } \\
\text { puas }\end{array}$ \\
\hline & Total & 574 & \\
\hline \multicolumn{2}{|l|}{ Rata-rata } & 95,67 & \\
\hline
\end{tabular}

Angket yang peneliti buat menggunakan skala Likert dengan hasil rata-rata kepuasan sebesar 96. Berdasarkan tabel diatas diketahui bahwa terdapat dua indikator kepuasan yang hasilnya dibawah rataratakepuasan konsumen, yaitu indikator kesediaan konsumen untuk merekomendasikan produk XL kepada orang lain dan indikator memprioritaskan produk XL. Adanya indikasi ketidakpuasan ini menunjukkan adanya risiko kehilangan konsumen, jika konsumen beralih kepada produk pesaing maka akan terjadinya penurunan penjualan yang berisiko untuk menurunkan pendapatan perusahaan.

PT. XL Axiata Tbk. menawarkan berbagai produk untuk memenuhi kebutuhan komunikasi konsumen, mulai dari GSM, Prabayar, Layanan Data, Jaringan Domestik, Jaringan Internasional, MAds, XCloud, sampai Digital Merchant yang hampir sama dengan jenis produk pesaing, namun terdapat indikasi kurangnya kualitas produk pada indikator kinerja dimana kecepatan jaringan internet yang tidak seperti yang diiklankan dan kualitas jaringan seperti $3 \mathrm{G}$ hanya terdapat jaringan $2 \mathrm{G}$ pada masa 
tertentu serta jaringan yang tiba-tiba menghilang. Rendahnya kualitas produk akan menurunkan kepuasan konsumen yang menyebabkan konsumen menjadi tidak merekomendasikan produk XL dan tidak memprioritaskan produk XL.

Sedangkan pada harga yaitu tarif internet, biaya paket, terindikasi masalah keterjangkauan harga, dimana produk XL bukanlah produk yang paling terjangkau dibanding harga beberapa produk kompetitor seperti im3 dan tri, serta seringnya terjadi perubahan harga pada produk XL. Semakin tidak konsistennya harga bisa mempengaruhi keputusan pembelian dan loyalitas konsumen yang akan berdampak terhadap penjualan dan pendapatan perusahaan.

Semakin tinggi harga suatu produk, semakin tinggi pula harapan konsumen akan manfat yang diberikan oleh produk tersebut. Bila manfaat yang dirasakan konsumen setelah membeli produk lebih besar atau sama dengan manfaat yang diharapkannya maka konsumen akan kembali membeli dimasa yang akan datang, menjadi lebih setia hingga merekomendasikan produk tersebut kepada orang lain. Semakin tinggi harga suatu produk, maka daya saing produk tersebut akan semakin rendah, sehingga konsumen semakin tidak memprioritaskan produk tersebut.

Berdasarkan masalah kepuasan konsumen, serta informasi mengenai kualitas produk dan harga yang ditemukan peneliti pada pelanggan PT XL Axiata Tbk. maka penulis tertarik untuk melakukan penelitian untuk mencari tahu pengaruh kualitas produk dan harga terhadap kepuasan konsumen, sehingga judul dari skripsi ini adalah "Pengaruh Kualitas Produk dan Harga Terhadap Kepuasan Konsumen"

\section{Identifikasi Masalah}

Berikut ini merupakam masalah yang dapat diidentifikasi dalam penelitian ini:

1. Adanya indikasi ketidakpuasan konsumen PT XL Axiata Tbk. yakni tidak merekomendasikan produk kepada orang lain.

2. Adanya indikasi ketidakpuasan konsumen yakni tidak memprioritaskan produk PT XL Axiata Tbk.

3. Adanya indikasi rendahnya kinerja kartu XL yang tidak sesuai dengan yang diiklankan.
4. Adanya indikasi rendahnya kualitas jaringan kartu XL.

5. Adanya indikasi kurang terjangkaunya harga paket internet kartu XL

6. Adanya indikasi kurangnya daya saing harga produk PT XL Axiata Tbk.

\section{Batasan Masalah}

Berdasarkan latar belakang masalah, maka batasan masalah dari penelitian ini adalah : Kualitas Produk dan Harga sebagai variabel independen, dan variabel Kepuasan Konsumen sebagai variabel dependen. Kualitas konsumen dipengaruhi beberapa faktor, antara lain : faktor kualitas layanan, faktor emosional, saluran distribusi, promosi, dan biaya untuk memperkaya ilmu pengetahuan dibidang pemasaran.

\section{Rumusan Masalah}

Masalah yang dapat dirumuskan dalam penelitian ini adalah :

1. Adakah pengaruh kualitas produk terhadap kepuasan konsumen pengguna provider XL pada Mahasiwa Politeknik Negeri Medan?

2. Adakah pengaruh harga terhadap kepuasan konsumenpengguna provider XL pada Mahasiswa Politeknik Negeri Medan?

3. Adakah pengaruh kualitas produk dan harga terhadap kepuasan Konsumen pengguna provider XL pada Mahasiswa Politeknik Negeri Medan?

\section{Tujuan Penelitian}

Adapun tujuan dari penelitian ini adalah :

1. Untuk mengetahui pengaruh kualitas produk terhadap kepuasan konsumen

2. Untuk mengatahui pengaruh harga terhadap kepuasan konsumen

3. Untuk mengetahui pengaruh kualitas produk dan harga tehadap kepuasan konsumen.

\section{Kegunaan Penelitian}

Manfaat dilakukannya penelitian ini adalah :

1. Secara teoritis dapat menambah dan memperkaya studi mengenai kualitas produk 
dan harga terhadap kepuasan konsumen khususnya pada PT XL Axiata Tbk.

2. Secara praktis dapat menjadi masukan bagi PT XL Axiata Tbk. Dalam pengambilan keputusan dalam meningkatkan kualitas produknya, serta menjaga dan meningkatkan kepuasan konsumennya.

\section{TINJAUAN PUSTAKA}

\section{Kualitas Produk}

Menurut Kotler dan Keller (2007:4) produk adalah segala sesuatu yang dapat ditawarkan ke pasar untuk memuaskan keinginana atau kebutuhan. Produk-produk yang dipasarkan meliputi barang fisik, jasa, pengalaman, acara-acara, orang, tempat, properti, organisasi, dan gagasan.

\section{Harga}

Menurut Kotler dan Amstrong (2001:349) harga merupakan sejumlah uang yang dibebankan atas suatu produk atau jasa atau jumlah dari nilai yang ditukar konsumen atas manfaat-manfaat karena memiliki atau menggunakan produk atau jasa tersebut.

\section{Kepuasan Konsumen}

Kotler, et al., (1996) dalam Tjiptono (2008) menandaskan bahwa kepuasan pelanggan adalah tingkat perasaan seseorang setelah membandingkan kinerja atau hasil yang ia rasakan dibandingkan dengan harapannya.

\section{KERANGKA BERPIKIR}

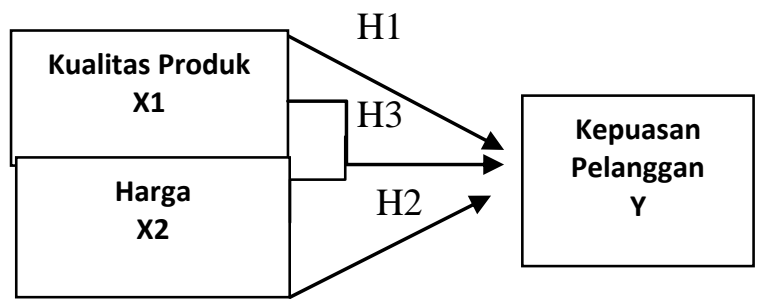

Gambar 2.1. Kerangka Konseptual

Kualitas produk dan harga akan mempengaruhi persepsi konsumen sebelum maupun sesudah membeli dan menggunakan suatu produk. Semakin tinggi kualitas produk dan semakin rendah harga suatu produk diharapkan akan semakin meningkatkan kepuasan konsumen. Semakin tinggi kinerja suatu produk dan semakin produk memiliki kesesuaian dengan spesifikasinya serta semakin sesuai dengan kualitas yang dipersepsikan konsumen diharapkan mampu memenuhi harapan dan kepuasan konsumen tersebut. Keistimewaan produk, kesediaan dalam membantu keluhan konsumen dan estetika produk diharapkan menambah minat konsumen untuk melakukan pembelian ulang. Semakin tinggi kehandalan dan daya tahan suatu produk diharapkan menimbulkan kesediaan konsumen untuk merekomendasikan produk kepada orang lain.

Semakin terjangkaunya harga suatu produk dan semakin sesuai harga dengan kualitas produk diharapkan semakin mampu memenuhi harapan konsumen. Semakin tinggi daya saing harga produk diharapkan meningkatkan minat pembelian ulang oleh konsumen. Semakin sesuai harga dengan manfaat produk yang dirasakan diharapkan menimbulkan kesediaan konsumen untuk merekomendasikan produk kepada orang lain.

\section{METODE PENELITIAN}

Penelitian ini menggunakan metode deskriptif kuantitatif. Pendekatan ini bertujuan untuk mengetahui bagaimana hubungan yang signifikan antara variabel yang diteliti sehingga kesimpulan yang akan memperjelas gambaran mengenai gambaran objek yang diteliti. Data yang dikumpulkanmelalui angket dianalisis dengan menggunakan metode deskriptif sehingga dapat diperoleh gambaran yang sebenarnya mengenai variabel penelitian berdasarkan data, yang menjadi populasi adalah mahasiswa Politeknik Negeri Medan yang berjumlah 45 orang, teknik pengambilan sampel digunakan dalam penelitian ini adalah menggunakan metode sampel jenuh, yakni teknik yang mewakilli populasi. Teknik analisis data yang digunakan adalah analisis regresi linear berganda setelah memenuhi asumsi klasik menyangkut normalitas, multikolinearitas, dan heterokedastisitas. Penarikan kesimpulan atas hipotesis dilakukan dengan cara uji $\mathrm{t}$ dan uji $\mathrm{F}$ pada level signifikansi $5 \%$. Keseluruhan tabulasi dan pengelolaan data menggunakan software SPSS versi 18.

\section{HASIL PENELITIAN}

Uji Regresi Linear Berganda 
Model persamaan regresi linear berganda sebagai berikut :

$$
Y=9,671+0,534 X_{1}-0,251 X_{2}
$$

Nilai konstanta a sebesar 9,671, nilai bX bebesar $_{1}$ 0,534 , dan nilai $\mathrm{bX}_{2}$ sebesar $-0,251$.

Nilai $\mathrm{bX}_{1}$ nilai menunjukkan besarnya pengaruh variabel $X_{1}$ (kualita produk) terhadap nilai variabel $\mathrm{Y}$ (kepuasan konsumen). Pengaruh ini mempunyai arti apabila kualitas produk ditingkatkan maupun diturunkan satu-satuan, maka kepuasan konsumen akan mengalami peningkatan atau pennurunan sebesar 0,534.

Nilai $\mathrm{bX}_{2}$ menunjukkan besarnya pengaruh variabel $\mathrm{X}_{2}$ (harga) terhadap nilai variabel $\mathrm{Y}$ (kepuasan konsumen). Pengaruh ini mempunyai arti apabila harga ditingkatkan maupun diturunkan satu-satuan, maka kepuasan konsumen akan mengalami pningkatan maupun penurunan sebesar $-0,251$.

\section{Hasil Uji t}

Uji parsial (uji t) digunakan untuk melihat pengaruh variabel independen terhadap variabel dependen secara parsial.

Hasil uji t diperoleh hasil sebagai berikut :

a. Nilai $t_{\text {hitung }}$ variabel kualitas produk sebesar 6.133 bernilai lebih besar dibandingkan dengan nilai $t_{\text {tabel }}$ 1,70. Sehingga; $\mathrm{H} 0$ ditolak dan $\mathrm{H} 1$ diterima, artinya variabel kualitas produk berpengaruh positif dan signifikan terhadap kepuasan konsumen PT XL Axiata Tbk.

b. Nilai $t_{\text {hitung }}$ variabel harga sebesar $-2,292$ bernilai lebih kecil dari nilai $t_{\text {tabel }}$ sebesar 1,70 namun berada di daerah kritis, ini berarti $\mathrm{HO}$ ditolak dan $\mathrm{H} 1$ diterima, artinya harga berpengaruh negatif dan signifikan terhadap kepuasan konsumen PT XL Axiata Tbk.

\section{Hasil uji F}

Untuk menguji hipotesis ini digunakan statistik $\mathrm{F}$ dengan kriteria pengambilan keputusan jika nilai $F_{\text {hitung }}$ lebih besar dari $F_{\text {tabel }}$, maka Ho ditolak dan $\mathrm{H}_{3}$ diterima. Pengaruh variabel bebas terhadap variabel terikat akan diuji pada tingkat signifikansi $(\alpha) 5 \%$.

Diperoleh bahwa $F_{\text {hitung }}$ sebesar 22,890 lebih besar dibandingkan $\mathrm{F}_{\text {tabel }}=3,34$ dan signifikan $0.000^{\mathrm{a}}$. Hal ini berarti mengindikasi bahwa hasil penelitian $\mathrm{H}_{0}$ ditolak $\mathrm{H}_{3}$ diterima. Perbandingan antara $\mathrm{F}_{\text {hitung }}$ dan $\mathrm{F}_{\text {tabel }}$ dapat membuktikan bahwa secara simultan variabel kualitas produk dan harga berpengaruh secara poritif dan signifikan terhadap kepuasan konsumen PT XL Axiata Tbk.

\section{Koefisien Determinasi $\left(\mathbf{R}^{2}\right)$}

Koefisien Determinasi bertujuan untuk mengukur seberapa jauh kemampuan model dalam menerangkan variabel terikat. Nilai $\mathrm{R}^{2}$ akan berkisar antara 0 sampai 1 , jika determiner $\mathrm{R}^{2}$ semakin besar atau mendekati 1 (satu) maka hubungan variabel bebas $\left(\mathrm{X}_{1}, \mathrm{X}_{2}\right)$ terhadap variabel $(\mathrm{Y})$ semakin kuat. Jika nilai $\mathrm{R}^{2}$ semakin kecil atau mendekati 0 (nol), maka hubungan variabel bebas $\left(\mathrm{X}_{1}, \mathrm{X}_{2}\right)$ terhadap variabel terikat (Y) semakin lemah.

Menunjukkan $\mathrm{R}$ Adjusted square sebesar 0,499 berarti variabel kepuasan konsumen dapat dijelaskan oleh variabel kualitas produk dan harga sebesar 49,9\% sedangkan sisanya $(100 \%-49,99 \%=$ $50,1 \%$ ) dipengaruhi oleh variabel lain yang tidak diteliti dalam penelitian ini seperti kualitas pelayanan, faktor emosional konsumen, saluran distribusi, promosi, biaya dan kemudahan.

\section{PEMBAHASAN}

Data dalam penelitian ini diperoleh dengan menyebarkan angket kepada responden dan mengumpulkannya kembali. Untuk mengetahui pengaruh kualitas produk dan harga terhadap kepuasan konsumen PT XL Axiata Tbk. penelitian melakukan pengujian analisis data dengan menggunakan bantuan program SPSS.

\section{Pengaruh Kualitas Produk dan Harga Terhadap Kepuasan Konsumen.}

Hasil uji parsial (uji t) mengenai pengaruh kualitas produk terhadap kepuasan konsumen dapat dilihat dari Nilai $t_{\text {hitung }}$ sebesar $6.133>$ nilai $t_{\text {tabel }}$ 1,70. Dapat disimpulkan bahwa kualitas produk berpengaruh positif dan signifikan terhadap kepuasan konsumen PT XL Axiata Tbk. Hal ini konsisten dengan penelitian Alghwerr, Bach (2014) yang menemukan bahwa kualitas produk berpengaruh terhadap kepuasan konsumen.

\section{Pengaruh Harga Terhadap Kepuasan Konsumen}

Hasil uji parsial mengenai harga terhadap kepuasan konsumen dapat dilihat dari nilai $t_{\text {hitung }}$ sebesar - 
$2,292<1,70$ namun berada di daerah kritis artinya harga berpengaruh negatif dan signifikan terhadap kepuasan konsumen PT XL Axiata Tbk. Hal ini konsisten dengan penelitian yang dilakukan Alelign, Rao, Obse (2014) yang menemukan bahwa harga berpengaruh terhadap kepuasan konsumen.

\section{KESIMPULAN DAN SARAN}

\section{KESIMPULAN}

Berdasarkan analisis dan pembahasan yang telah diuraikan pada bab sebelumnya, maka peneliti mengambil kesimpulan, yaitu:

1. Berdasarkan pengujian hipotesis secara parsial (uji t) diperoleh nilai $t_{\text {hitung }}$ variabel kualitas produk lebih besar dari nilai $t_{\text {tabel }}$ yaitu nilai $t_{\text {hitung }} 6.133>$ nilai $t_{\text {tabel }} 1,70$. Sehingga; $H 0$ ditolak dan H1 diterima, artinya variabel kualitas produk berpengaruh positif dan signifikan terhadap kepuasan konsumen PT XL Axiata Tbk.

2. Berdasarkan pengujian hipotesis secara parsial (uji t) diperoleh nilai $t_{\text {hitung }}$ variabel harga lebih kecil dari nilai $t_{\text {tabel }}$ yaitu $=$ nilai $t_{\text {hitung }}-2,292<$ nilai $t_{\text {tabel }} 1,70$, namun berada di dalam daerah kritis sehingga; H0 ditolak dan $\mathrm{H} 1$ diterima, artinya variabel harga berpengaruh negatif dan signifikan terhadap kepuasan konsumen PT XL Axiata Tbk.

3. Hasil pengujian penelitian menyatakan bahwa nilai $F_{\text {hitung }}$ lebih besar dari $F_{\text {tabel }}$ yaitu nilai $F_{\text {hitung }}$ $22,890>$ nilai $F_{\text {tabel }} 3,34$. Dengan demikian dapat disimpulkan bahwa ada pengaruh yang positif dan signifikan antara kualitas produk dan harga terhadap kepuasan konsumen PT XL Axiata Tbk..

4. Hasil penelitian ini didukung oleh nilai Adjusted $R$ Square (R2) 0,522 atau 52,2\% yang artinya bahwa secara serempak variabel kualitas produk dan harga mempunyai pengaruh sebesar 52,2\% terhadap kepuasan konsumen PT XL Axiata Tbk., sedangkan sisanya $47,8 \%$ dijelaskan oleh variabel-variabel di luar penelitian ini yang dapat mempengaruhi kepuasan konsumen, seperti faktor emosional konsumen, saluran distribusi, promosi, biaya dan kemudahan.

\section{SARAN}

1. Variabel kualitas produk berpengaruh terhadap kepuasan konsumen, karena itu perlu untuk mempertahankan kesesuaian produk dengan kebutuhan konsumen dan paket yang lengkap. Kualitas produk belum memiliki daya saing yang tinggi, untuk itu perusahaan perlu meningkatkan kualitas jaringan sehingga produk dapat bekerja dengan baik dan dapat berguna secara maksimal oleh konsumen. Selain itu hal yang perlu ditingkatkan adalah masa aktif paket sehingga dapat digunakan oleh konsumen dalam waktu yang lama sehingga produk akan memberikan manfaat yang semaksimal mungkin kepada konsumen yang akan mempengaruhi kepuasannya.

2. Variabel harga mempengaruhi kepuasan konsumen, sehingga perlu untuk mempertahankan tarif atau harga paket yang murah dan terjangkau, serta mempertahankan kesesuaian harga dengan kualitas produk. Harga produk yang ditetapkan belum memiliki daya saing yang tinggi terhadap produk pesaing, sehingga perlu untuk ditingkatkan lagi agar memiliki daya saing harga yang tinggi.

3. Pada variabel kepuasan konsumen, perusahaan perlu untuk mempertahankan kesesuaian produk dengan harapan konsumen, keinginan konsumen dalam membeli kembali serta kemampuan produk dalam memenuhi kebutuhan konsumen. Sedangkan hal yang perlu untuk ditingkatkan adalah kesediaan konsumen untuk merekomendasikan produk kepada orang lain.

4. Untuk peneliti selanjutnya, hasil penelitian ini dapat diajukan sebagai bahan acuan khususnya untuk penelitian yang berkaitan dengan kualitas produk dan harga terhadap kepuasan konsumen, diharapkan juga untuk peneliti selanjutnya agar menambah variabel lainnya yang dapat mempengaruhi kepuasan konsumen seperti kualitas layanan, faktor emosional, saluran distribusi, promosi, dan biaya untuk memperkaya ilmu pengetahuan dibidang pemasaran.

\section{DAFTAR PUSTAKA}

Abdullah, Dayang, Nailul, Munna, Abang., and Francine, Rozario. 2009. Influence of service and product quality towards customer satisfaction. International Journal Vol: 3, No: 5. 
Abdullah, Thamrin., dan Francis, Tantri. 2012. Manajemen pemasaran. Jakarta: PT Raja Grafindo.

Alelign, Dereje., and Prasada, Rao., and Geda, Obse. 2014. The impact of marketing mix on customer satisfaction. IJAR: 2348-7666.

Alghwery, Haifa., and Christian, Bach. 2014. Customer satisfaction. IJISR.: 23518014 Vol. 3. 2.

Daryanto. 2011.manajemen pemasaran. Bandung: Satu Nusa.

Ginting, Hartimbul. 2011. Manajemen pemasaran cetakan 1. Bandung: CV. Yrama Widya.

Hidayat, Anang. 2006. Strategi six sigma. Jakarta: PT Elek Media Komputindo.

Jahanshahi, Asghar, Afshar. And Mohammed, Ali, Hajizadeh, Gashi., and Seyed, Abbas, Mirdamadi., and Khaled, Nawaser., and Seyed, Mohamad, Sadeq, Khaksar. 2011. Study the effects of customer service and product quality on customer satisfaction and loyalty. International journal of humanities and social science Vol. 1. No. 7.

Kadhim, Faris, Abdullah., and Thaer, Abdullah., and Mahir, Abdullah. 2015. Effects of marketing mix on customer Satisfaction. International Journal :2394-7500.

Kaiman, Hidayat., dan Andri, Yan, Prima, Zani. 2013. Influence of service and price of house flat on Customer Satisfaction. IJBMI: 2319-8028.

Khan, Shahzad., and Syed, Majid, Hussain., and Fahad, Yaqoob. 2012. Determinants of customer satisfaction in fast food industry. International journal of management and strategy: Vol. No. 3, Issue 4.

Kotler, Philip., and Gary Armstrong. 2008. PrinsipPrinsip Pemasaran edisi 12 jilid 2. Jakarta: Erlangga.

Lamb, Hair, Mcdaniel. 2001. pemasaran buku 2. Jakarta: Salemba Empat.
Lovelock, Christoper., and Lauren, Wright. 1999. Manajemen pemasaran jasa. PT Indeks.

Lovelock, Wirtz, Mussry. 2010. Pemasaran Jasa manusia, teknologi, strategi jilid 1 edisi ketujuh. Jakarta: Erlangga.

Lupiyoadi, Rambat., dan Akhiraini, Hamdani. 2006. manajemen pemasara jasa. 2006. Jakarta: Salemba Empat.

Malik, Muhammad, Ehsan., and Muhammad, Mudasar, Ghafoor., and Hafiz, Kashif, Iqbal. 2012. Impact of brand image, service quality and price on customer satisfaction. IJBSS vol. 3. No. 23.

Ngoc, Khuong, Mai., and Tran, Tran, Uyen. 2015. Factors affecting guest perceived service quality product, and satisfaction. Vietnam: Joams. 3. 4.284-291.

Nitisusastro, Mulyadi. 2010. Perilaku Konsumen. Bandung: Alfabeta.

Rangkuti, Freddy. 2009. Strategi promosi yang kreatif dan analisis kasus integrated marketing communication. Jakarta: Gramedia.

Sugiyono. 2003. Metode penelitian administrasi. Bandung: Alfabeta.

Sarjono, Julianita. 2011. SPSS vs LISREL, Sebuah Pengantar, Aplikasi untuk Riset. Jakarta: Salemba Empat.

Tjiptono, Fandy. 2008. Strategi pemasaran edisi III. Yogyakarta: Andi. 